\title{
Preface
}

I N The Lieutenant Nun I analyze the various ways in which the early modern Spanish transgenderist Catalina de Erauso, more commonly known as the "Monja Alférez" (Lieutenant Nun), has been constructed, interpreted, marketed, and consumed by the dominant culture and divergent audience groups from the seventeenth through the twentieth centuries in Europe, Latin America, and the United States. This study investigates the cultural function of transvestite narratives through an analysis of the Lieutenant Nun figure presented in literary, theatrical, iconographic, and cinematic adaptations during nearly four hundred years in Spain, England, Latin America, and North America. I argue that the ways in which Erauso's experience has been transformed into a public spectacle help explain the enduring popularity and economic success of transgender narratives as well as how they expose and manipulate spectators' fears and desires. This book explores what happens when the private experience of the transgenderist is shifted to the public sphere and thereby marketed as a hybrid spectacle for the curious gaze of the general audience.

Chapter I, "Hybrid Spectacles: Lesbian Desire, Monsters, and Masculine Women in Early Modern Spain," provides the neces- 
sary background to contextualize the reception and interpretation of transgenderism during the life of Catalina de Erauso. This section reviews the ambiguity and the cultural constructedness of concepts and practices such as hybrid monsters, lesbianism and homoerotic images, cross-dressing, and biological sex assignment during the early modern period in order to understand how a transgendered lesbian figure could gain celebrity status as well as financial compensation and religious affirmation in seventeenth-century Spain. Analyses of sources from official and popular culture demonstrate how Erauso's icon tapped into the early modern fascination with hybrid monsters and the essentialist belief that masculine women were the product of a prenatal transmutation. Likewise, the Lieutenant Nun's popularity during the seventeenth century was a response to the marketability of female transvestism in history, literature, and theater, justified by the need or desire for selfprotection (chastity and safety), escapism, adventure, patriotism, the support of patriarchy, romantic and economic motives, and the sex appeal of the revealing garments.

Chapter 2, "Celebrity and Scandal: The Creation of the Lieutenant Nun in the Seventeenth Century," examines the contradictory politics of the Monja Alférez icon as public spectacle during the seventeenth century in Spain and in the New World. This chapter provides an analysis of the different versions of Erauso's life presented between I6I8 and I653 in legal petitions, testimonies, letters, three relaciones (news pamphlets), her autobiography, an episode from a picaresque novel, literary and iconographic portraits, and a play. While these narratives reveal a variety of identities - rebellious nun, heroic soldier, deviant criminal, exemplary virgin, and monstrous hybrid spectacle - the one image that is present in the seventeenth-century adaptations but silenced in subsequent periods is that of the lesbian. In particular, this chapter explores the strategies of cultural production and the preferences of the seventeenth-century consumer/spectator involved in the selling and consumption of the Lieutenant Nun celebrity. The manifestations of this icon, represented as both killer lesbian and virgin military hero, also attempt to reveal Catalina de Erauso's reactions to becoming the object of the public's curious gaze. Although the church and state interpreted Erauso's alleged lesbianism, in conjunction with proof of her virginity, as nonthreatening (nonreproductive and nonpenetrative) desire, other popular culture narratives such 
as the broadsides and a comedia linked her same-sex attraction to aggression and deceit. In the end, however, the presentation of Erauso's lesbian desire facilitated official and public approval of her transgenderism: she refrained from heterosexual relations while participating in Spain's project of empire-building. Moreover, the association of her vices with homosexual desire ensured that her personal life would not become an acceptable model for future women.

In chapter 3, "Melodrama and the De-Lesbianized Reconstruction of the Lieutenant Nun in the Nineteenth Century," I discuss the nineteenthcentury transformation of the popular icon in Spanish literary journals, a zarzuela (Spanish operetta), a Mexican play, and historical novels from Mexico and Spain. While Catalina de Erauso represented a hybrid spectacle that produced admiration, titillation, and shock during the seventeenth century, the nineteenth century was highly critical of the lesbian celebrity. Consequently, writers and critics read the Lieutenant Nun as a demonized lesbian or reconstructed her into a heterosexual or asexual figure who is temporarily transgressive only because of her transvestism and violent nature but not due to her desire for other women. The transformation of the Lieutenant Nun's image from the seventeenth century to the nineteenth century is not surprising considering the dramatic change in how lesbianism was perceived from one period to another. While nonpenetrative sexual activity between women during the early modern period was not seen as a serious threat to orthodox values - especially in comparison to male homosexuality-same-sex relations in the nineteenth century were viewed as a criminal pathology that had to be corrected.

The only nineteenth-century adaptation that presents a more sympathetic image of a lesbian lieutenant nun is found in an anonymous novel from Mexico. This version, nonetheless, portrays same-sex desire as an entertaining erotic spectacle as well as a mechanism that ensures the protagonist's heterosexual chastity.

Chapter 4, "From Cinema to Comics: The Re-Lesbianization of the Lieutenant Nun in the Twentieth Century," builds on the analyses of previous chapters to demonstrate how Latin American, Spanish, and North American films and novels, a play, and various comics and stories for young adults have manipulated the Lieutenant Nun icon for varying and, at times, opposing ideological purposes. An examination of twentieth- 
century manifestations of Erauso's life reveal a gradual re-lesbianization of the protagonist that reflects the changing attitudes toward homosexuality among certain audiences. The 1944 Mexican film starring María Félix follows the nineteenth-century model by portraying Erauso as the heterosexual femme fatale. Forty years later, however, Javier Aguirre directed a Spanish film that presents Erauso's life as a story of tragic lesbian love, while a year later, in 1987, the North American filmmaker Sheila McLaughlin released the only version to privilege the image of a triumphant homosocial resolution. The twentieth-century prose narratives from the I950s and I970s, on the other hand, tend to "correct" Erauso's same-sex desire by portraying her as an asexual protagonist, by rehabilitating the transgressive lesbian, or by presenting homoeroticism in terms of a heterosexual configuration. In other words, in the heterobiased adaptations the protagonist desires women because she feels like a man.

The twentieth-century sequential art narratives or comic strips likewise propose an asexual reading of the homoerotic episodes in Erauso's life narrative. While those from Spain seek to teach readers about the Basque heroine through both serious and humorous representations, a comic book published in Mexico highlights the action-adventure features of Erauso's life. These three sequential art narratives either suppress homoeroticism or present a historical figure who resisted the sexual advances of other women deceived by the disguise. This chapter, nonetheless, demonstrates the implicit potential for a queer "rereading" of the transvestite narratives (by analyzing the visual impact of the unconvincing disguise in episodes that feature same-sex flirtation) despite the apparent attempt to correct or police lesbian desire in many of the adaptations based on Erauso's experience. 


\section{(3) Acknowledgments}

SO MANY FRIENDS and colleagues have contributed to the ideas developed in this book that I cannot thank them all. I would, however, like to offer special gratitude to Adrienne Martín, Anne Cruz, Mary Elizabeth Perry, Kristine Ibsen, and Lourdes Torres for providing insightful criticism that helped enrich my thinking about the Lieutenant Nun icon. I also wish to acknowledge my generous colleagues at the University of Kansas. Roberta Johnson, Lee Skinner, Jonathan Mayhew, Isidro Rivera, Danny Anderson, Tony Rosenthal, Luis Corteguera, and Marta Vicente offered perceptive and rigorous comments for which I am very grateful. Special thanks go to Juan Velasco, Jorge Galindo, and Ramón Velasco Moreno for their emotional and critical support as I tracked down yet another obscure representation of the Lieutenant Nun. I am equally indebted to my colleagues at the University of Kentucky, in particular, to Jay Allen, Margaret Jones, and Dianna Niebylski for their counsel on the final revisions. In addition, I would like to express my appreciation for support from the Program for Cultural Cooperation Between Spain's Ministry of Culture and United States' Universities, the General Research Fund at the University of Kansas, and the Tinker Field Research Fund. Finally, I 
would like to thank Mary Daniels, María José Delgado, Renata Fernández, and especially Lynn Porter, Paula Courtney, and Pam LeRow at the University of Kansas, as well as Rachel Chance, Leslie Tingle, Allison Faust, Alison Tartt, and Ellen McKie at the University of Texas Press for their invaluable assistance in the preparation of the manuscript. 